\title{
Fermentable Sugars from Agrowastes Using Cellulase Enzymes from Local White Rot Fungi Pycnoporus sanguineus
}

\author{
(Gula Fermentasi daripada Sisa Pertanian Menggunakan Enzim Selulase daripada Kulat Pereput Putih Tempatan \\ Pycnoporus sanguineus) \\ Norhazmiza Ahmad Safri, Rafidah Jalil \& Mohd Sahaid Kali1* \\ Faculty of Engineering and Built Environment, Universiti Kebangsaan Malaysia, Malaysia \\ Forest Research Institute of Malaysia, Malaysia
}

\begin{abstract}
The viability offermentation process is very much depends on the use of a cheap carbon source from lignocellulosic materials. It needs to hydrolyse into simple and readily metabolize carbohydrate using cellulase enzyme. Pycnoporus sanguineus has been able to produce cellulase enzyme with high enzyme activity that can convert lignocellulosic materials into fermentable sugar. P. sanguineus was culture using $\alpha$-cellulose as carbon source for enzyme production via submerged fermentation (SMF) at different agitation speeds (100 and $150 \mathrm{rpm}$ ). Crude cellulase enzyme extracted from fermentation broth by centrifugation was used in hydrolysis of sawdust and sugarcane bagasse at different substrate concentrations (1-5\% w/v). It was found that crude cellulase enzyme contain three main enzymes components i.e. endoglucanase, exoglucanase and xylanase with maximum activity of $1.55,0.45$ and $8.0 \mathrm{U} / \mathrm{mL}$ respectively that achieved after four days of cultivation at agitation speed of 150 $\mathrm{rpm}$. The most suitable temperature and substrate concentration for sawdust and sugarcane bagasse hydrolysis by cellulase from P. sanguineus was at $30^{\circ} \mathrm{C}$ and $5 \%(\mathrm{w} / \mathrm{v})$ where sugarcane bagasse produced maximum of $59.10 \mathrm{~g} / \mathrm{L}$ fermentable sugar as compared to from sawdust $(58.84 \mathrm{~g} / \mathrm{L})$. Fermentable sugar productivity was the highest $(2.45 \mathrm{~g} / \mathrm{L} / \mathrm{h})$ when sawdust was use compared to $0.50 \mathrm{~g} / \mathrm{L} / \mathrm{h}$ for sugarcane bagasse. Fermentable sugar produced from agrowastes using cellulase enzymes of P. sanguineus has highest potential as a feedstock for biofuels and biochemicals production.
\end{abstract}

Keywords: Lignocellulosic biomass; Cellulose; Fermentable sugars; Pycnoporus sanguineus

\section{INTRODUCTION}

Sugarcane bagasse is abundantly produced as lignocellulosic residues from agricultural sources which are almost $380 \times$ $10^{6}$ ton per year (Sanchez 2009). Lignocellulosic biomass comprises of agricultural, industrial and forestry waste (Kumar et al. 2009; Liming \& Xueliang 2004; Maitan-Alfenas et al. 2015). It is becoming a promising feedstock for fermentable sugar production since it is a cheap and renewable resources that can reduced the cost of raw materials (Maki et al. 2009; Percival Zhang et al. 2006). Accumulation of daily waste in a large quantity is a major factor on environmental problem such as air pollution as well as water pollution. Burning up the disposal wastes becomes one of the problems that increased the global warming issues by producing greenhouse gases (Khelil \& Cheba 2014).

Generally, lignocellulosic biomass consists of cellulose, hemicellulose and lignin (Khelil \& Cheba 2014; Wyk 1999). Lignocellulosic biomass can be hydrolysed into fermentable sugars via enzymatic hydrolysis using lignocellulolytic enzymes. Lignocellulolytic enzymes are natural biocatalysts that are very important for lignocellulose degradation (Jahangeer et al. 2005). Lignocellulolytic enzymes can be divided into cellulolytic, xylanolytic and ligninolytic enzymes. Most of the commercial enzymes are produced from microorganisms such as fungi. Famous fungi that produced these enzymes are from Trichoderma spp. and Aspergillus spp.

Pycnoporus sanguineus is one of the white-rot fungi (Sanchez 2009; Yoon et al. 2012) that have high capability to hydrolyse lignocellulosic biomass into fermentable sugars due to the secretion of lignocellulolytic enzymes. These fermentable sugars have high commercial interests in fermentation industries that could be used as feedstock for the biofuels production (Chu \& Feng 2013). Enzymes involved in hydrolysis process known as cellulase that consist of major enzymes namely endoglucanase and exoglucanase that hydrolyze cellulose into glucose and also xylanase enzymes to hydrolyze hemicellulose into xylose. Recently, higher demand of enzymes applied by enzymes based industry become the major factor to explore new potential to utilize local sources for enzyme production to fulfill the industry needs. The aim of this study is to produce cellulase enzymes from $P$. sanguineus and to evaluate the ability of cellulase enzymes produced from $P$. sanguineus to hydrolyse different agrowastes such as sawdust and sugarcane bagasse into fermentable sugars. 
METHODOLOGY

MICROORGANISM

Pycnoporus sanguineus (PS) was obtained from Forest Research Institute of Malaysia (FRIM). The fungus was grown on potato dextrose agar (PDA) at $30^{\circ} \mathrm{C}$ for seven (7) days. It was sub-cultured once a month and keep at $4^{\circ} \mathrm{C}$.

MEDIUM AND INOCULUM PREPARATION

Mandels's medium was used for cellulase enzymes production via submerged fermentation. This medium consisted of 20.0 g a-cellulose, $20.0 \mathrm{~g} \mathrm{CoCl}_{2} .6 \mathrm{H}_{2} \mathrm{O}, 1.4 \mathrm{~g} \mathrm{ZnSO}_{4} .7 \mathrm{H}_{2} \mathrm{O}, 1.6$ g $\mathrm{MnSO}_{4} .7 \mathrm{H}_{2} \mathrm{O}, 5.0$ g FeSO$_{4} \cdot 7 \mathrm{H}_{2} \mathrm{O}, 0.2$ g Tween $80,1.0$ g Peptone, $0.3 \mathrm{~g} \mathrm{MgSO}_{4} .7 \mathrm{H}_{2} \mathrm{O}, 0.4 \mathrm{~g} \mathrm{CaCl}_{2} 2 \mathrm{H}_{2} \mathrm{O}, 2.0 \mathrm{~g}$ $\mathrm{KH}_{2} \mathrm{PO}_{4}, 1.4 \mathrm{~g}\left(\mathrm{NH}_{4}\right)_{2} \mathrm{SO}_{4}$, and $0.3 \mathrm{~g}$ Urea and distilled water was added to make one (1) liter of medium solution. Inoculum was prepared by transferring $10 \mathrm{~mm}$ agar plug of mycelia of PS into eight (8) different Erlenmeyer flasks that contained $100 \mathrm{~mL}$ of Mandels's medium. It was incubated at $30^{\circ} \mathrm{C}, \mathrm{pH} 4.2$ and was shaken at different agitation speed (100 and $150 \mathrm{rpm}$ ) for seven (7) days. During the fermentation, samples were taken from each flask at 24 hours interval for growth profiles and enzymes assay analysis. Culture with higher enzymes activities was used in enzymatic hydrolysis process.

\section{ENZYMATIC HYDROLYSIS}

Enzymatic hydrolysis was carried out at different substrate (sawdust and sugarcane bagasse) concentrations (1-5\%) with $20 \mathrm{~mL}$ of enzyme loading and $80 \mathrm{~mL}$ of medium. It was agitated at $150 \mathrm{rpm}$ at different reaction temperatures of $30^{\circ} \mathrm{C}, 40^{\circ} \mathrm{C}$ and $50^{\circ} \mathrm{C}$. The samples were taken every 24 hours for 144 hours (6 days) until the yield of reducing sugar was constant.

\section{REDUCING SUGAR DETERMINATION}

Reducing sugar was measured after 48 hours of incubation time. $5 \mathrm{~mL}$ of sample from each flask was taken daily and was centrifuged at $8000 \mathrm{rpm}$ for 10 minutes. The supernatant was taken for sugar analysis. A volume of $1 \mathrm{~mL}$ of each sample (supernatant) was put into test tube with $2 \mathrm{~mL}$ of DNS reagent. It was boiled for 5 minutes. The absorbance was measured by spectrophotometer at $540 \mathrm{~nm}$. The concentration of reducing sugars was calculated based on glucose standard curve (Miller 1959).

\section{ENZYME ASSAY: ENDOGLUCANASE (CMCASE)}

A volume of $1 \mathrm{~mL}$ of supernatant and $1 \mathrm{~mL}$ of $1 \%$ (w/v) carboxymethylcellulase (CMC) in citrate buffer at $\mathrm{pH} 4.8$ was prepared to determine the endoglucanase enzyme activity. The reaction mixture was incubated at $50^{\circ} \mathrm{C}$ for 30 minutes. After that, $2.0 \mathrm{~mL}$ DNS solution was added into the reaction mixture and was heated in boiling water bath for five (5) minutes. Then, it was placed in an ice-cooled water bath to cool down the solution. The absorbance of mixture was read at $540 \mathrm{~nm}$ using spectrophotometer. One unit of endoglucanase enzyme activity is defined as $1 \mu \mathrm{mol}$ reducing sugar (glucose) released per mL enzyme per minute (Zhang et al. 2009).

\section{ENZYME ASSAY: EXOGLUCANASE (AVICELASE)}

Exoglucanase enzyme activity was measured by using $1.25 \%$ $(\mathrm{w} / \mathrm{v})$ Avicel in acetate buffer. $0.4 \mathrm{~mL}$ of supernatant and $1.6 \mathrm{~mL}$ of Avicel suspension was transferred into the test tube. The reaction was incubated at $50^{\circ} \mathrm{C}$ for 2 hours. Then, $2.0 \mathrm{~mL}$ of DNS solution was added and was boiled for 5.0 minutes. The absorbance was measured at $490 \mathrm{~nm}$ using spectrophotometer. One unit of exoglucanase enzyme activity is defined as $1 \mu \mathrm{mol}$ reducing sugar (glucose) released per mL enzyme per minute (Zhang et al. 2009).

ENZYME ASSAY: XYLANASE

Xylanase enzyme assay was carried out by mixing $0.2 \mathrm{~mL}$ of supernatant with $1.8 \mathrm{~mL} \mathrm{1 \%}$ xilan in citrate buffer $(\mathrm{pH}$ 5.2). It was incubated at $50^{\circ} \mathrm{C}$ for 5 minutes. Then, $2 \mathrm{~mL}$ DNS reagent was added and was boiled for 5 minutes. The xylose standard curve was used to measure xylanase enzyme activity. The absorbance was measured using spectrophotometer at $540 \mathrm{~nm}$. One unit of xylanase enzyme activity is defined as $1 \mu \mathrm{mol}$ reducing sugar (xylose) released per $\mathrm{mL}$ enzyme per minute (Miller 1959).

\section{RESULTS AND DISCUSSION}

\section{CELLULASE ENZYME PRODUCTION}

Effect of two different agitation speeds (100 and $150 \mathrm{rpm}$ ) on enzymes production was studied based on enzymes activities (Figure 1 and 2). The enzymes production was carried out via submerged fermentation at temperature of $30^{\circ} \mathrm{C}$ for 7 days. Three types of enzymes activities were measured that are endoglucanase, exoglucanase and xylanase. For agitation speed of $100 \mathrm{rpm}$, it was found that, the highest endoglucanase, exoglucanase and xylanase were $1.55 \mathrm{U} / \mathrm{mL}$, $0.45 \mathrm{U} / \mathrm{mL}$ and $8.00 \mathrm{U} / \mathrm{mL}$ respectively and were obtained on day four of fermentation (Figure 1).

While, for agitation speed of $150 \mathrm{rpm}$ (Figure 2), it was found that the xylanase enzymes activity was the highest (5.79 U/mL) and was obtained on day two (2) fermentation. Maximum endoglucanase enzyme was $2.69 \mathrm{U} / \mathrm{mL}$ obtained on day three (3) while maximum exoglucanase enzyme activity was $0.62 \mathrm{U} / \mathrm{mL}$ obtained on day four (4).

Among the enzymes studied, xylanase activity was the highest and this finding is similar to the previous report that has been carried out using $P$. sanguineus. Maximum xylanase enzymes activity was $10.01 \mathrm{U} / \mathrm{mL}$ compared to endoglucanase and exoglucanase enzymes that were 8.43 $\mathrm{U} / \mathrm{mL}$ and $0.06 \mathrm{U} / \mathrm{mL}$ respectively. There are significant differences between these studies and the enzyme produced 


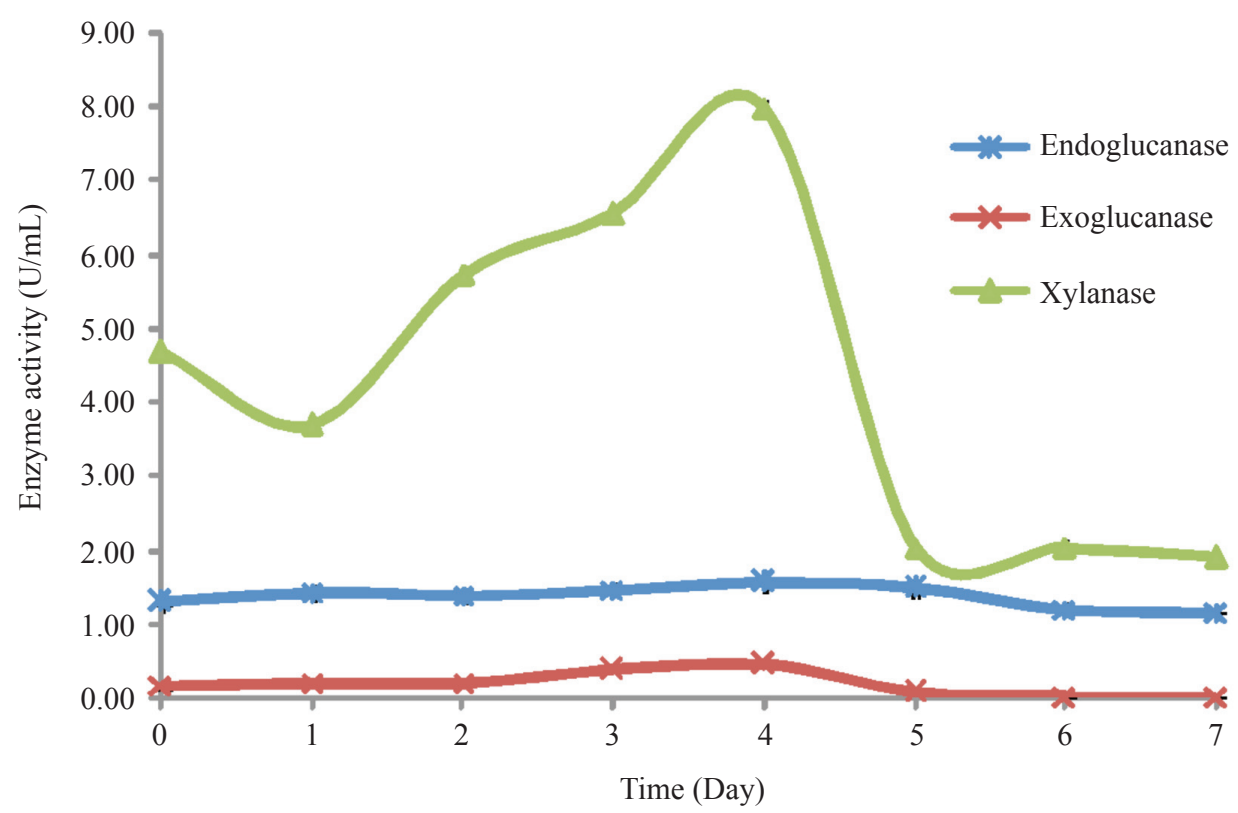

FIGURE 1. Enzymes Activity at agitation of $100 \mathrm{rpm}$

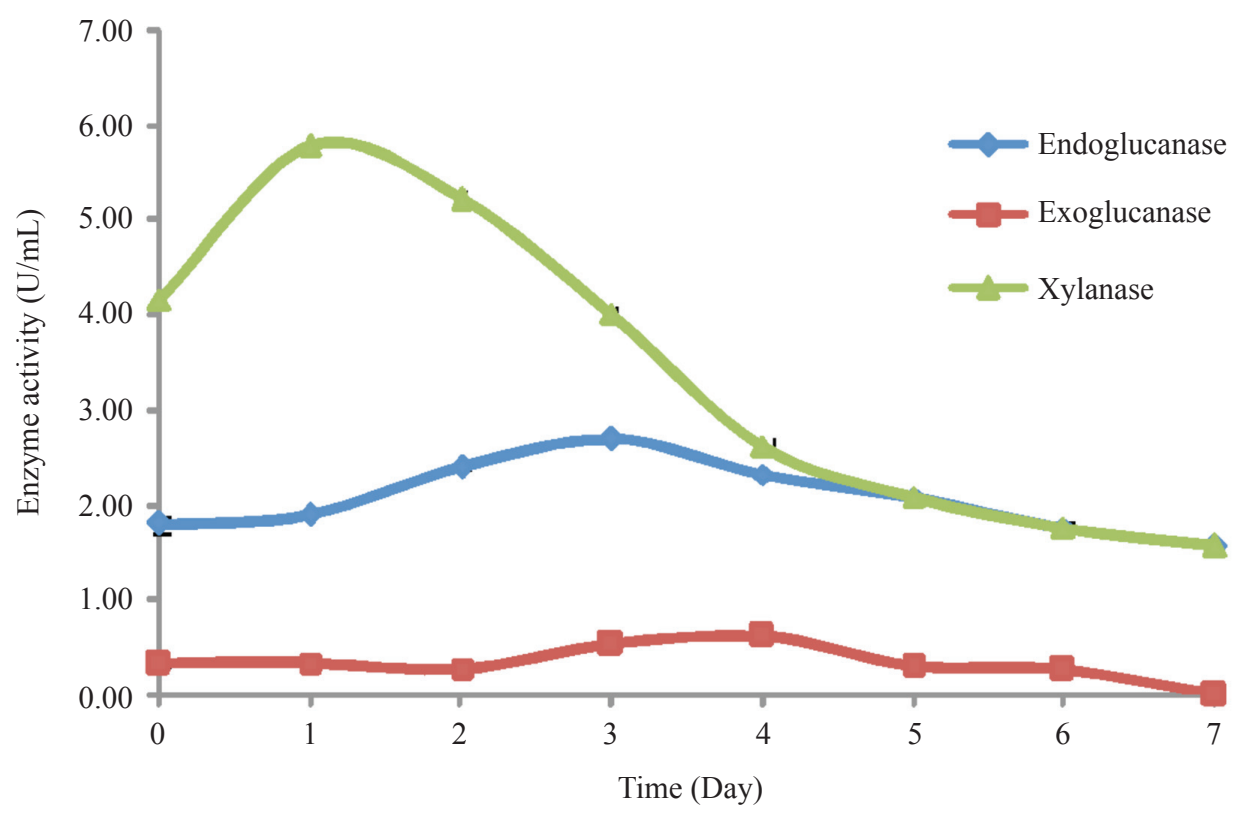

FIGURE 2. Enzyme Activity at agitation of $150 \mathrm{rpm}$

using different species of Pycnoporus sanguineus PF-2 with higher amount of substrate (Falkoski et al. 2012).

Comparison of enzymes activities between agitation of 100 and $150 \mathrm{rpm}$ were done in Table 1. It was shown that the different agitation speeds produced the highest enzyme activity at different incubation times. Maximum enzymes activity for agitation speed at $100 \mathrm{rpm}$ was on the fourth day while the agitation speed at $150 \mathrm{rpm}$ on day two and three. For both findings, enzymes production using higher agitation speed $(150 \mathrm{rpm})$ produced higher endoglucanase and exoglucanase which were $74 \%$ and $38 \%$ higher than $100 \mathrm{rpm}$ respectively. Enzyme activities and agitation speed relates each other in which increasing speed of agitation will produce higher cellulolytic enzymes activities (Santosh et al. 2014). The agitation speed causes the oxygen to disperse uniformly in media and also to ensure a well mixing of nutrients during fermentation that promotes the growth of fungus and secretion of enzymes. Unlike endo and exoglucanases, xylanase enzymes activity decreased of about $38 \%$ when agitation speed was increased from 100 to $150 \mathrm{rpm}$. This might be due to high shear force and fungal cell disruption that lowers the xylanase enzyme production. However, xylanase enzymes productivity for agitation speed of $150 \mathrm{rpm}$ higher than 100 $\mathrm{rpm}$ which is $2.90 \mathrm{U} / \mathrm{mL} /$ day and $2.0 \mathrm{U} / \mathrm{mL} /$ day respectively with $45 \%$ higher. 
TABLE 1. Comparison of enzyme activity at different agitation speeds

\begin{tabular}{lcc}
\hline Enzyme Activity & $\begin{array}{c}\text { Maximum Enzyme } \\
\text { Agitation 100 rpm }\end{array}$ & $\begin{array}{c}\text { Activity }(\mathrm{U} / \mathrm{mL}) \\
\text { Agitation } 150 \mathrm{rpm}\end{array}$ \\
\hline Endoglucanase & 1.55 (Day 4) & 2.69 (Day 3) \\
Exoglucanase & 0.45 (Day 4) & 0.62 (Day 4) \\
Xylanase & 8.00 (Day 4) & 5.79 (Day 2) \\
\hline
\end{tabular}

CELLULASE ENZYMES REACTION ON SAWDUST AND SUGARCANE BAGASSE DURING ENZYMATIC HYDROLYSIS

Effect of Reaction Time Enzymatic hydrolysis of sawdust and sugarcane bagasse were carried out at temperature of $30^{\circ} \mathrm{C}$ with $1 \%$ substrate concentration at different reaction times (0-144 hours). Comparisons of yield for both biomasses were based on its reducing sugars content (Figure 3).

It was found that sugarcane bagasse $(23.17 \mathrm{~g} / \mathrm{L})$ has higher reducing sugars compared to sawdust (17.74 g/L). However, sawdust has the fastest reaction rate of fermentable sugars production compared to sugarcane bagasse where maximum reducing sugars of sawdust obtained after 24 hours incubation with reaction rate of $0.74 \mathrm{~g} / \mathrm{L} / \mathrm{hr}$. While, for sugarcane bagasse, maximum reducing sugars was obtained after 96 hours with reaction rate of $0.24 \mathrm{~g} / \mathrm{L} / \mathrm{hr}$ that is $68 \%$ decreased. Liu et al. 2016 reported that increasing reducing sugars rapidly showed high rate of enzymatic reaction.

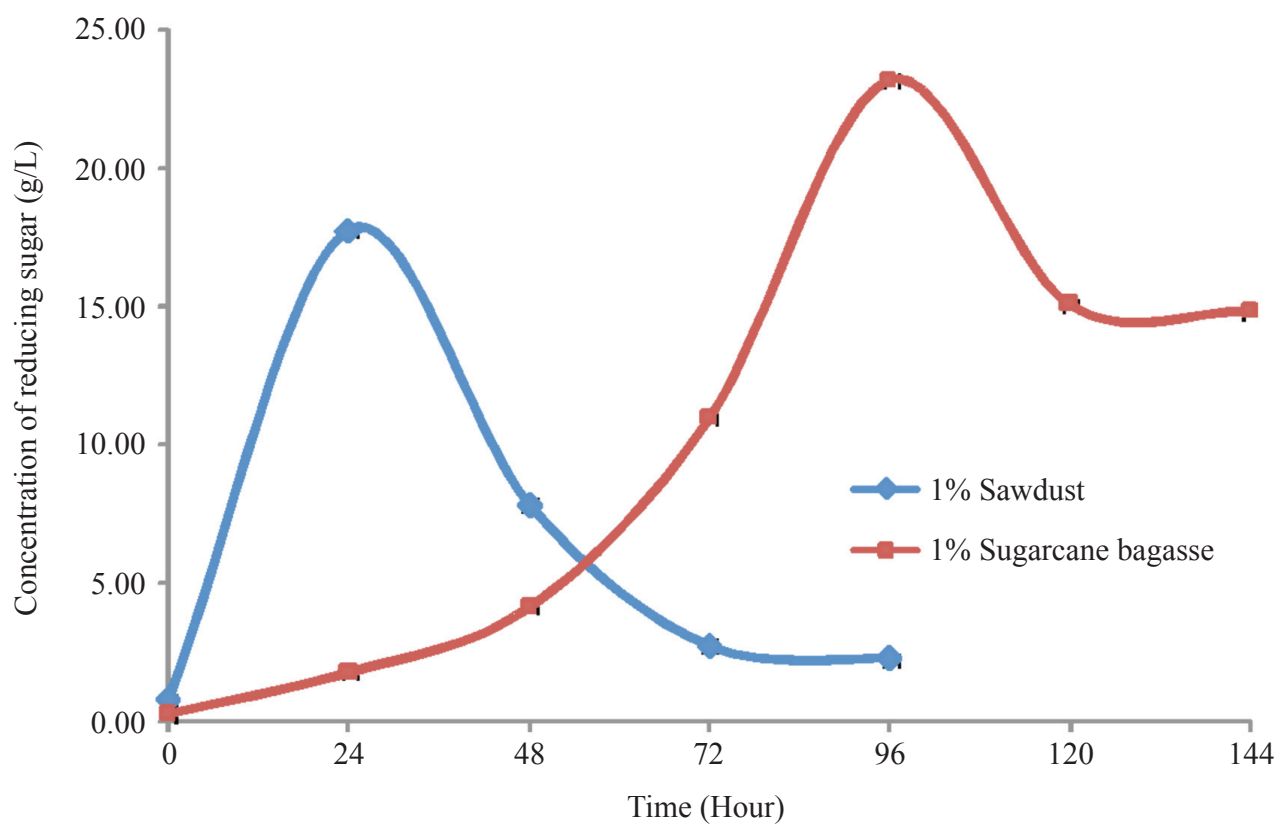

FIGURE 3. Concentration of reducing sugar at different reaction times

Effect of Substrate Concentration Substrate concentration gave an effect to the enzymatic hydrolysis process although different types of substrates were used to produce fermentable sugars. Figure 4 shows the enzymatic reaction of sawdust and sugarcane bagasse using different substrate concentrations $(1-5 \% \mathrm{w} / \mathrm{v})$.

Enzymatic hydrolysis of sawdust was carried out at constant temperature of $30^{\circ} \mathrm{C}$ using the same volume of reaction medium with different substrate concentrations $(1-5 \% \mathrm{w} / \mathrm{v})$. Based on finding in section 3.2.1, maximum reducing sugars was obtained after 24 hours reaction time. For the effect of substrate concentration study, the comparison of reducing sugar produced was based on maximum reaction time (24 hours). It was found that reducing sugars increased when substrate concentration increased. Maximum reducing sugars was obtained using $5 \%(\mathrm{w} / \mathrm{v})$ sawdust with $58.84 \mathrm{~g} / \mathrm{L}$ of fermentable sugar yield followed by $4 \%(\mathrm{w} / \mathrm{v})$ sawdust $(54.92$ $\mathrm{g} / \mathrm{L}$ ) that shows an increasing of $7.1 \%$ when concentration of substrate increased. These slight differences were due to maximum concentration of sugar being hydrolyzed during enzymatic treatment. However, $1 \%(\mathrm{w} / \mathrm{v})$ of sawdust has the lowest reducing sugar concentration of $17.74 \mathrm{~g} / \mathrm{L}$. This low concentration is due to minimum biomass being hydrolyzed during enzymatic hydrolysis.

For sugarcane bagasse, the enzymatic hydrolysis reaction conditions were the same as sawdust. However, reducing sugars for sugarcane bagasse was analyzed after 96 hours reaction time. This is based on maximum reaction time obtained during previous work. It was found that, maximum reducing sugars $(59.10 \mathrm{~g} / \mathrm{L})$ were obtained using $5 \%(\mathrm{w} / \mathrm{v})$ substrate concentration. Fermentable sugars production using $1 \%(\mathrm{w} / \mathrm{v})$ substrate produced minimum yield of 23.17 $\mathrm{g} / \mathrm{L}$. Based on findings for both biomasses for different substrate concentration, it was found that higher substrate concentration gave higher fermentable sugars yield (Idrees et al. 2014). Fermentable sugar production rate for sawdust $(2.45 \mathrm{~g} / \mathrm{L} / \mathrm{hr})$ was higher than sugarcane bagasse $(0.62 \mathrm{~g} / \mathrm{Lhr})$ with more than $100 \%$ efficiency. 


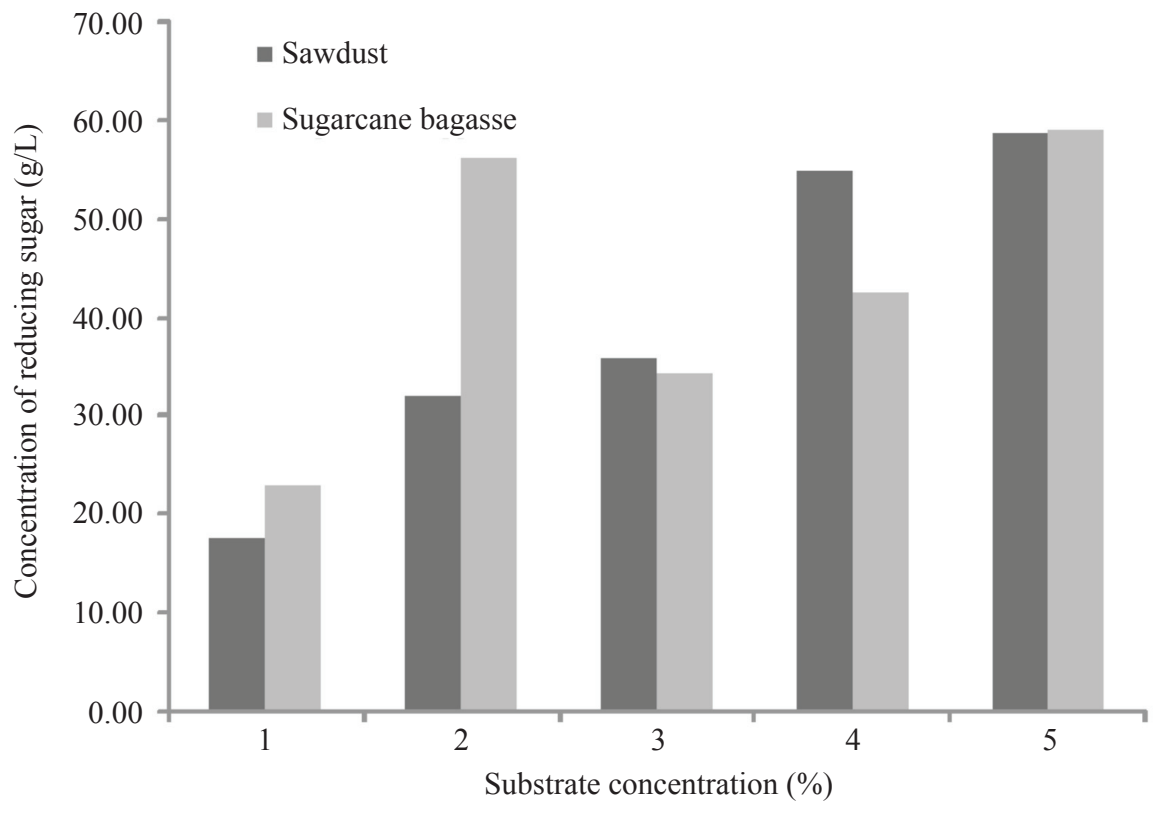

FIGURE 4. Effects of substrate concentrations on fermentable sugar production

Effect of Reaction Temperature The effect of fermentable sugars produced using $5 \%(\mathrm{w} / \mathrm{v})$ substrate concentration at different reaction temperatures $\left(30,40\right.$ and $\left.50^{\circ} \mathrm{C}\right)$ were also studied and were shown in Figure 5. The most suitable reaction temperature for both biomass was obtained at $30^{\circ} \mathrm{C}$ as compared to 40 and $50^{\circ} \mathrm{C}$.

For sawdust, the enzymatic reaction increased rapidly after 24 hours incubation time. Maximum fermentable sugars yield $(58.84 \mathrm{~g} / \mathrm{L})$ was obtained at temperature of $30^{\circ} \mathrm{C}$ as compared to $13.27 \mathrm{~g} / \mathrm{L}$ that was obtained at temperature of $50^{\circ} \mathrm{C}$. While for sugarcane bagasse, maximum fermentable sugars yield $(59.10 \mathrm{~g} / \mathrm{L})$ was obtained at $30^{\circ} \mathrm{C}$ that only showed $0.44 \%$ different compared to sawdust. At $50^{\circ} \mathrm{C}$, fermentable sugars of $15.23 \mathrm{~g} / \mathrm{L}$ were obtained from sugarcane bagasse. Based on previous research, the sugar concentration of bagasse is higher than sawdust after hydrolyzing it using enzyme from Aspergillus oryzae ITCC-485701 (Begum \& Alimon 2011). Increasing reaction temperature would decrease the fermentable sugars production due to fungal effectiveness decrease. At temperature of $30^{\circ} \mathrm{C}$, it is very close to natural growth of fungi and this is the reason of higher sugar yield. Besides, enzymatic hydrolysis carried out at low temperature is suitable for industrial applications due to less energy consumption (Sri devi et al. 2015). Moreover at this temperature, longer reaction time does not give any significant different to the sugar yield (Mezule et al. 2015).

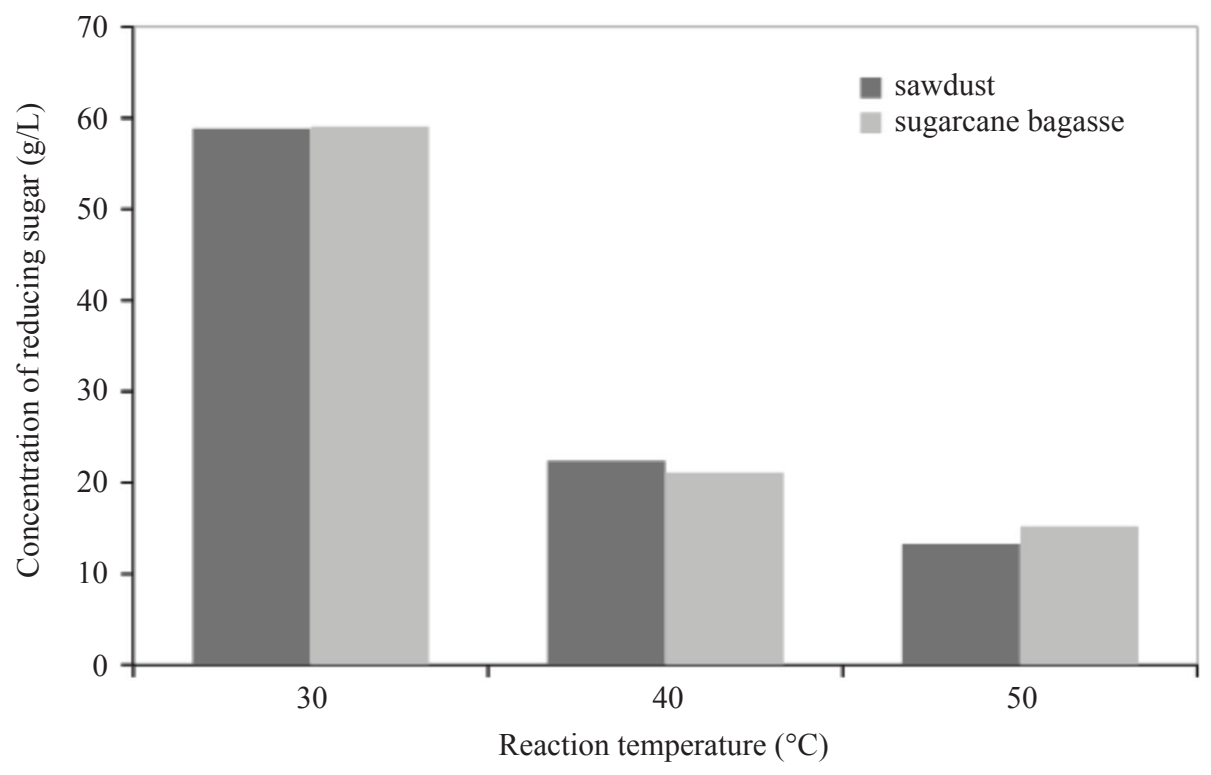

FIGURE 5. Effect of reaction temperature on fermentable sugars production 


\section{CONCLUSION}

Production of cellulolytic as well as xylanolytic enzymes from fungi of Pycnoporus sanguineus can be used as catalyst for enzymatic hydrolysis of sawdust and sugarcane bagasse to produce fermentable sugars. High yield of fermentable sugars produced was influenced by factors such as reaction time, substrate concentration and reaction temperature. Maximum fermentable sugars yield were obtained from sawdust (58.84 $\mathrm{g} / \mathrm{L})$ and sugarcane bagasse $(59.19 \mathrm{~g} / \mathrm{L})$ after 24 and 96 hours incubation time at temperature of $30^{\circ} \mathrm{C}$, agitation speed of $150 \mathrm{rpm}$ and $5 \%(\mathrm{w} / \mathrm{v})$ substrate concentration. Application of local enzymes of $P$. sanguineus gave high potential for fermentable sugars production that could reduce the dependency on commercial enzymes as well as reducing the production cost.

\section{ACKNOWLEDGEMENT}

The authors would like to thank Universiti Kebangsaan Malaysia (UKM) for their financial support under Research University (RU) Grant GUP-2016-006.

\section{REFERENCES}

Bakri, Y., Mekaeel, A. \& Koreih, A. 2011. Influence of agitation speeds and aeration rates on the xylanase activity of Aspergillus niger SS7. Brazilian Archives of Biology and Technology 54(4): 659-664.

Begum, M.F. \& Alimon, A.R. 2011. Assessment of some wild Aspergillus species for cellulase production and characterization. African Journal of Microbiology Research 5(27): 4739-4747.

Chu, K. H. \& Feng, X. 2013. Enzymatic conversion of newspaper and office paper to fermentable sugars. Process Safety and Environmental Protection 91(1-2): 123-130.

Falkoski, D.L., Guimarães, V.M., de Almeida, M.N., Alfenas, A.C., Colodette, J.L. \& de Rezende, S.T. 2012. Characterization of cellulolytic extract from Pycnoporus sanguineus PF-2 and its application in biomass saccharification. Applied Biochemistry and Biotechnology 166: 1586-1603.

Idrees, M., Adnan, A., Bokhari, S.A. \& Qureshi, F.A. 2014. Production of fermentable sugars by combined chemo-enzymatic hydrolysis of cellulosic material for bioethanol production. Brazilian Journal of Chemical Engineering 31(2): 355-363.

Jahangeer, S., Khan, N., Jahangeer, S., Sohail, M., Shahzad, S., Ahmad, A. \& Khan, S. A. 2005. Screening and characterization of fungal cellulases isolated from the native environmental source. Pakistan Journal of Botany 37(3): 739-748.
Khelil, O. \& Cheba, B. 2014. Thermophilic cellulolytic microorganisms from western Algerian sources: Promising isolates for cellulosic biomass recycling. Procedia Technology 12: 519-528.

Kumar, P., Kumar, P., Barrett, D.M., Barrett, D.M., Delwiche, M.J., Delwiche, M.J. \& Stroeve, P. 2009. Methods for pretreatment of lignocellulosic biomass for efficient hydrolysis and biofuel production. Industrial and Engineering Chemistry 48(8): 3713-3729.

Liming, X. \& Xueliang, S. 2004. High-yield cellulase production by Trichoderma reesei ZU-02 on corn cob residue. Bioresource Technology, 91(3): 259-262.

Liu, X., Xu, Q., Liu, J., Yin, D., Su., S. \& Ding, H. 2016. Hydrolysis of cellulose into reducing sugars in ionic liquids. Fuel 164: 46-50.

Maitan-Alfenas, G.P., Visser, E.M. \& Guimarães, V.M. 2015. Enzymatic hydrolysis of lignocellulosic biomass: converting food waste in valuable products. Current Opinion in Food Science 1: 44-49.

Maki, M., Leung, K.T. \& Qin, W. 2009. The prospects of cellulase-producing bacteria for the bioconversion of lignocellulosic biomass. International Journal of Biological Sciences 5(5): 500-516.

Mezule, L., Dalecka, B. \& Juhna, T. 2015. Fermentable sugar production from lignocellulosic waste. Chemical Engineering Transactions 43: 619-624.

Miller, G.L. 1959. Use of dinitrosalicylic acid reagent for determination of reducing sugar. Analytical Chemistry 31(3): 426-428.

Percival Zhang, Y.H., Himmel, M.E. \& Mielenz, J.R. 2006. Outlook for cellulase improvement: Screening and selection strategies. Biotechnology Advances 24(5): 452-481.

Sanchez, C. 2009. Lignocellulosic residues: Biodegradation and bioconversion by fungi. Biotechnology Advances 27(2): 185-194.

Santosh Kumar, S., Edla, S. \& Pabba, S.K. 2014. Optimization and characterization of thermostable endo and exocellulases by Humicola sp. SKESMBKU03. Science, Technology and Arts Research Journal 3(4): 107-115

Sridevi, A., Narasimha, G., Ramanjaneyulu, G., Dileepkumar, K., Rajasekhar Reddy, B. \& Suvarnalatha Devi, P. 2014. Saccharification of pretreated sawdust by Aspergillus niger cellulase. Biotechnology 5: 883-892.

Wyk, J. P. H. Van. 1999. Saccharification of paper products by cellulase from Penicillium funiculosum and Trichoderma reesei. Biomass and Bioenergy 16(3): 239-242.

Yoon, L. W., Ngoh, G. C. \& Chuaa, A. S. M. 2012. Simultaneous production of cellulase and reducing sugar from alkali-pretreated sugarcane bagasse via solid state fermentation. BioResources 7(4): 5319-5332.

Zhang, Y.H.P., Hong, J. \& Ye, X. 2009. Cellulase assays. Journal of Molecular Biology 581: 213-231. 
Norhazmiza Ahmad Safri

Rafidah Jalil

*Mohd Sahaid Kalil

Faculty of Engineering and Built Environment

Universiti Kebangsaan Malaysia

43600 UKM, Bangi, Selangor Darul Ehsan, Malaysia

Forest Research Institute of Malaysia (FRIM)

52109 Kepong Selangor, Malaysia.

*Corresponding author; email: sahaid@ukm.edu.my

Received Date: $1^{\text {st }}$ August 2017

Accepted Date: $28^{\text {th }}$ November 2017

In Press date: $15^{\text {th }}$ December 2017

Published date: $31^{\text {st }}$ December 2017 
